JOURNAL Of

CONTEMPORARY INDONESIAN ART

Jurusan Seni Murni

FSR ISI Yogyakarta

ISSN: 2442-3394

E-ISSN: 2442-3637

\section{HIPOKRIT SEBAGAI IDE PENCIPTAAN KARYA SENI LUKIS}

\author{
Oleh : \\ Mario Viani \\ Institusi: Institut Seni Indonesia Yogyakarta
}

\begin{abstract}
ABSTRAK
Hipokrit adalah sifat kepura-puraan dan kemunafikkan diri yang berdampak buruk bagi lingkungan sosial. Peri hal konsepsi dari hipokrisi dijabarkan dalam bentuk visual pada tugas akhir mengenai hal-hal yang menyangkut sisi-sisi gelap dari manusia dalam hal ini merujuk pada kepura-puraan dan kemunafikkan dalam mencapai segala sesuatu yang diinginkanya tanpa peduli dampak buruk bagi lingkunganya, yang diekspresikan ke dalam karya lukis. Dalam merumuskan tentang sifat hipokrisi ke dalam sebuah bentuk karya seni akan digambarkan sebagai seseorang yang bertopeng, Topeng menjadi simbol untuk seseorang yang menyembunyikan karakter aslinya dibalik topeng yang dikenakannya. Hal ini dilihat dari pengertian-pengertian hipokrisi yang telah dijabarkan pada bab sebelumnya di mana seorang yang selalu menyimpan keburukan hati dan menampilkan kebaikan, kereligiusan, kebijaksaan dalam bersosial. Melihat hal tersebut maka diperlukan pemahaman tentang topeng yang akan dihadirkan ke dalam sebuah karya, sehingga tidak merusak makna luhur yang sudah tertanam selama ini.

Kata kunci: Hipokrit, munafik, karya lukis, bentuk visual
\end{abstract}

\begin{abstract}
Hypocrit is the nature of pretense and self-hypocrisy which has a bad impact on the social environment. In terms of the conception of hypocracy described in visual form in the final project regarding matters concerning the dark sides of man, in this case it refers to pretense and hypocrisy in achieving everything he wants regardless of the negative impact on the environment, which is expressed in in painting. In formulating the hypocrite nature into a form of art work will be depicted as someone who is a mask, the mask becomes a symbol for someone who hides his true character behind the mask he wears. This can be seen from the hypocratic notions that have been described in the previous chapter where a person who always keeps a bad heart and displays kindness, religiosity, wisdom in socializing. Seeing this, it is necessary to understand the masks that will be presented in a work, so that they do not destroy the noble meaning that has been embedded so far.

Key words: Hypocritical, hypocritical, painting, visual form
\end{abstract}




\section{PENDAHULUAN}

Manusia adalah makhluk yang berhadapan dengan diri sendiri dan menghadapi realitas dengan kesukaran, persoalan, dan lain sebagainya. Pada sisi yang lain manusia juga merupakan makhluk yang berada dan menghadapi alam kodrat. Manusia merupakan satu kesatuan dengan alam tetapi juga berjarak, dalam artian dengan segenap akal budinya manusia mampu memandang, berpendapat, atau mengubah dan mengolah alam. (N. Drijarkara S. J, 1978:7), Pada kehidupan sehari-hari, manusia dihadapkan persoalan-persoalan sosial di lingkungan sekitarnya.

Dalam kehidupan sosial, manusia membawa dirinya berperan serta pada kehidupan bermasyarakat yang lebih komplek. Persoalan sosial yang sangat dekat adalah adanya rasa dalam diri atau sekelompok orang untuk dipandang baik, pintar, atau bahkan paling religius di lingkungan sosial, namun hal tersebut

Gejala sosial yang tampak pada personalitas manusia seperti ini dinamakan sebagai hipokrit atau dalam Kamus Besar Bahasa Indonesia diartikan sebagai kemunafikan, orang yang suka berpura-pura, kepurapuraan yang mengakibatkan dampak negatif pada lingkunganya. (Dendy Sugono, 2015:502)

Berdasarkan uraian yang telah dipaparkan, dirasa cukup menarik untuk melakukan pendalaman materi mengenai bagaimana bentuk, sikap, dan karakteristik yang khas dari tindakan hipokrit itu terjadi dalam kehidupan sehari-hari ataupun dalam lingkungan masyarakat sekitar, serta dampak nyata yang dirasakan dari tindakan hipokrit. Kejadian-kejadian tersebut menjadi bahan acuan terhadap diri sendiri atau orang lain dan diwujudkan menjadi tema dalam proses penciptan karya seni lukis.

Hipokrisi lazim ditemukan pada lingkupan kecil maupun yang lebih luas. Pada kondisi sehari-hari sebagai contoh, ada pada lingkungan anak-anak Sekolah Menengah Atas (SMA). Bangku SMA merupakan masa remaja ketika seseorang mulai mencari-cari jati diri dan minat. Tidak jarang ditemui siswa berlombalomba menampilkan diri sebagai seorang pemberani dan paling ditakuti dikalangan teman-temannya agar dipandang sebagai sejatinya dirinya. Tidak jarang pula ditemui siswa yang memiliki kecenderungan untuk mencari muka atau berbuat baik agar mendapat perhatian lebih dari guru dan atau disegani teman-temannya. Semuanya dilakukan dengan menutupi sifat asli yang sebenarnya melekat pada siswa tersebut.

Kasus yang dijabarkan setelah ini merupakan contoh kasus yang lebih konkrit yang pernah dialami. Di suatu SMA di kota Purwokerto, ada seorang siswa A, yang mencoba untuk mendekati siswa B. Saat itu A mendekati B hanya demi mendapatkan perlindungan dari $\mathrm{C}$ yang merupakan siswa sekolah lain. Selain itu A sedang bermasalah dengan C karena A banyak mengumbar janji pada $\mathrm{C}$, berpurapura memiliki banyak kenalan guru yang mampu memberikan kunci jawaban Ujian Nasional (UN) yang akan diselenggarakan. Kemudian UN berlangsung A tidak mampu menepati janjinya. C mencoba mencari A untuk menagih janji sekaligus memberikan pelajaran atas kebohongannya. Keadaan tersebut membuat A semakin tertekan dan mencari jalan keluar dengan cara menfitnah $\mathrm{C}$ untuk meyakinkan B bahwa A patut untuk dibela. A mengatakan bahwa $\mathrm{C}$ telah menerornya karena A tidak memberikan apa yang $\mathrm{C}$ mau, seperti uang, makanan dan lain-lain; memposisikan dirinya sebagai orang baik yang menjadi korban. B pun marah karena merasa bahwa A yang selama ini baik di matanya, sudah diperlakukan tidak baik oleh $\mathrm{C}$. Tidak berselang lama B dan $\mathrm{C}$ pun bertemu dan pertikaian tidak bisa dihindari. A yang sudah dibela merasa semakin tinggi hati dan semakin merasa paling benar.

Kasus lain dalam kehidupan seharihari adalah ketika seseorang menjelekjelekkan orang lain tanpa sepengetahuan orang yang bersangkutan. Namun saat orang tersebut hadir senyuman lebar, dan keramahan terpampang. Seseorang yang menjelek-jelekan tersebut menyatakan 
apabila kejujuran adalah hal yang utama dalam hidup, namun apayang dilakukannya berbanding terbalik. Keramahan dan kebaikan pada akhirnya hadir hanya dalam rupa "topeng" yang menutupi sifat asli. Di balik itu semua iri dengki dan kebencian menyelimuti hati.

Berdasarkan

pengalamanpengalaman empiris yang telah disebutkan di atas, hiprokrisi manusia menjadi menarik untuk dituangkan ke dalam karya seni, dalam hal ini seni lukis. Warna kontras yang menyertai sifat hipokrisi bagaikan Yin dan Yang di dalam jiwa manusia, di mana kepentingan yang membentuk sifat yang terlihat bertabrakan dengan sifat asli yang ditutupi. Topeng jiwa inilah yang menjadi latar belakang menarik untuk adanya penciptaan karya lukis dalam rangka tugas akhir ini. Hal tersebut memacu ide kreatif untuk menvisualisasikan karakteristikyang khas dari hipokrisi. Diharapkan nantinya, tugas akhir yang diberi judul "Hipokrit Sebagai Ide Penciptaan Karya Lukis" ini tidak hanya dapat menjadi lahan apresiasi namun juga lahan untuk instropeksi bagi penikmat maupun penulis.

\section{B. RUMUSAN PENCIPTAAN}

Berkaitan dengan permasalahan Hipokrit ada pula batasan-batasan dari permasalah tersebut yakni:

1. Karakter sikap hipokrit seperti apakah yang menarik untuk dijadikan karya seni?

2. Bagaimana memvisualisasikan bentuk dari sikap hipokrit dengan teknik dan warna ke dalam sebuah karya lukis?

\section{TUJUAN}

1. Menjelaskan dan mendeskripsikan persoalan bentuk tindakan hipokrit.

2. Memvisualkan apa dan bagaimana hipokrit dalam karya lukis.

\section{TEORI DAN METODE}

1. Teori

Karya seni diciptakan dengan proses yang panjang. Pada umumnya kegelisahan batin serta pengalaman-pengalaman yang pernah dilalui menjadi dasar terciptanya karya seni. Proses penciptaan karya seni setiap seniman tidaklah sama, tergantung dari pengalaman yang dilalui serta lingkungan kesenimannnya, fantasi atau imajinasi kreatif dari setiap seniman.

Pengalaman yang pernah dilalui dari seorang seniman akan diolah menjadi sebuah pemahaman dan diserap dalam pemikiran juga perasaan. Menghayati pengalaman diri menjadi salah satu cara atau proses memicu munculnya ide dalam menciptakan karya seni. Ide merupakan rancangan yang tersusun dalam pikiran dapat dipahami sebagai gambaran imajinal utuh yang melintas cepat. (Dendy Sugono,2015:512)

Bertolak dari dari pengertian tersebut maka ide menjadi faktor penting dalam menentukan konsep penciptaan karya seni dan melahirkan banyak bentuk gaya tergantung kreativitas setiap orang.

Kreativitas adalah kemampuan daya cipta seseorang dalam memunculkan sesuatu kedalam bentuk sebuah karya. (Dendy Sugono,2015:739)

Pada umumnya kekreativitasan mampu mewujudkan sebuah kebaruan atau sesuatu yang belum pernah diciptakan sebelumnya. Hal itu dapat diartikan bahwa seorang seniman memiliki daya untuk menciptakan sesuatu yang berbeda atau baru dari pengalaman yang pernah dilalui. Seperti yang diuraikan oleh M. Dwi Marianto dalam bukunya bahwa,

"Tindakan kreatif acap bermula dari melihat hal-hal biasa atau lumrah yang sudah begitu familiar namun dilihat dengan cara lain sehingga menjadi yang baru, atau asing sehingga merangsang keingintahuan kita. Maka benarlah apa yang pernah ditulis oleh Marcel Proust bahwa temuan itu tidak terletak pada pencarian landscape-landscape namun melainkan pada bagaimana memiliki mata yang baru". (M. Dwi Marianto, 2011:67)

Berawaldariidemakakekreativitasan dalam menuangkannya menjadi sebuah karya seni menjadi penting, sedangkan karya seni sendiri sebagai wadah dari 
ide untuk direalisasikan, sehingga bisa terwujud sesuai dengan keinginan si penciptanya. Dengan adanya pemahaman akan konsepsi penciptaan karya seni dirasa akan lebih mempermudah menuangkan ide ke dalam wujud karya lukis.

"Karya seni sendiri merupakan bentuk ekspresi yang diciptakan bagi persepsi kita lewat indra dan pencitraan, dan yang diekspresikan adalah perasaan maupun pengalaman yang telah dilalui. Perasaan disini dalam artian kegembiraan, kegelisahan akan sesuatu yang mengganjal, tekanan pikiran maupun emosi". (Jakob Sumardjo, 2000: 66)

Bertolak pada teori tersebut, maka hipokrisi pada tema tugas akhir ini menjadi sekumpulan pengalaman yang dirasa cukup membawa pengaruh besar dalam hidup. Oleh sebab itu pengalaman mengenai hipokrisi tersebut menjadi ide dasar dari penciptaan sebuah karya seni. Hipokrit sendiri secara etimologi berasal dari bahasa Yunani, yakni dari kata "Hupo" yang berati "under" atau "di bawah" serta "Krites" yang merujuk kepada seseorang yang menghakimi atau memberi, dan membuat pernyataan. (Elmer L. Grey, , 2017:67)

Hipokrit yang diutarakan tersebut mengacu pada pengertian seseorang yang memengaruhi khalayak umum dengan khotbahnya. Ciri yang mengindikasikan bahwa seseorang memiliki sifat hipokrit, seperti yang ditulis Dedeng Rosidi yaitu antara lain:

1. Pembohong dalam kaitannya adalah mengingkari apa yang ada dalam dirinya seperti contohnya seseorang yang berkata baik pada seseorang namun tidak dalam hatinya, atau sama halnya dengan seseorang yang banyak mengumbar janji namun ingkar.

2. Menjadikan sumpah bohong menjadi tameng

Dengan kata lain seseorang yang bersumpah palsu demi keamanan jiwa mereka atau demi menyelamatkan harta yang mereka miliki.
3. Baik di luar namun buruk di dalam hatinya

Seseorang yang lebih memilih dipandang orang baik dan menceritakan pada orang lain baik namun tidak pada hatinya. Hal itu dilakukan dengan keterpaksaan hanya demi menjaga citra diri yang baik terpuji dan dihormati orang banyak.

4. Manis perkataan buruk jiwanya.

Segala sesuatu yang dikatakannya akan terasa manis, indah, dan bagus namun berbanding terbalik dengan jiwanya yang buruk. (Dedeng Rosidi, 2007:7)

Pemahaman tentang ciri hipokrit yang sudah diuraikan di atas pun sering terjadi pada diri sendiri. Kecenderungan hipokrisi pada diri terjadi dari satu pribadi yang kemudian memengaruhi banyak orang dan meluas ke dalam ranah sosial yang lebih luas. Oleh karena itu perilaku hipokrisi dalam diri inilah yang menjadi pokok permasalahan dari proses penciptaan karya lukis ini.

Berkaitan dengan seni rupa khususnya seni lukis hipokrisi kerap dimetaforakan dengan sesosok figur memiliki dua wajah atau dua kepala dalam satu tubuh, hal itu mengacu pada pandangan C.G.Jung dalam mendefinisikan sifat hipokrisi yaitu sisi gelap manusia yang tidak disadari seseorang, atau seseorang yang mampu memengaruhi banyak orang lewat gaya bahasa, cara berpakaian dan lain sebagainya. Ada sisi berbeda yang disembunyikan dari dalam dirinya. (C. G. Jung, 1966:p. 26.)

C. G. Jung mengungkapkan bahwa setiap manusia membutuhkan perubahan didirinya. Namun tidak juga dengan memaksakan kehendaknya dengan jubah hipokrisi melainkan dengan kesadaran dirinya dan ilmu pengetahuannya. Dalam psikoanalisanya juga disebutkan bahwa kesadaran akan sisi gelap pada dirinya akan lebih berdampak baik pada diri mereka 
juga sesamanya. Hal tersebut karena sifat kepuraan-puraan ada pada setiap diri manusia, sehingga tidak menutup kemungkinan bahwa kepura-puraan juga terkadang diperlukan dalam bersosial guna menjaga keharmonisan bersosial antar sesama.

2. Metode

Hipokrisi adalah kata sifat, yang merujuk pada salah satu sifat manusia yang mempunyai dampak buruk bagi lingkungannya, oleh karena itu dalam penuangannya ke dalam sebuah bentuk karya akan mengacu pada simbol tertentu dan metafora tertentu. Simbol menurut Sussane K. Langer "merupakan wahana bagi konsepsi manusia tentang objek". (I. Wibowo Wibisono, 1977: 144), jika kita menyebutkan nama seseorang, yang tergambar dalam pikiran kita adalah konsepsi dari orang tersebut apakah dia seorang pria yang berpendidikan atau wanita sebagai ibu rumah tangga dan lain sebagianya. Semua itu diwakili oleh namanya, sehingga tidak perlu menghadirkan orang secara langsung. Melihat teori tersebut maka dalam konsep penciptaan ini, dalam menggambarkan bagimana sifat hipokrisi akan digunakan simbol-simbol umum serta simbol pribadi, sehingga konsepsi tentang hipokrisi bisa tersampaikan kepada penikmat seni melalui simbol.

Dalam merumuskan tentang sifat hipokrisi ke dalam sebuah bentuk karya seni akan digambarkan sebagai seseorang yang bertopeng, Topeng menjadi simbol untuk seseorang yang menyembunyikan karakter aslinya dibalik topeng yang dikenakannya. Hal ini dilihat dari pengertian-pengertian hipokrisi yang telah dijabarkan pada bab sebelumnya di mana seorang yang selalu menyimpan keburukan hati dan menampilkan kebaikan, kereligiusan, kebijaksaan dalam bersosial. Melihat hal tersebut maka diperlukan pemahaman tentang topeng yang akan dihadirkan ke dalam sebuah karya, sehingga tidak merusak makna luhur yang sudah tertanam selama ini.

Topeng sendiri, khususnya di
Indonesia, secara umum merupakan penutup muka yang terbuat dari kayu, kertas dan bahan lainnya dalam bentuk yang berbeda-beda seperti binatang, setan, manusia, dewi, dan lain sebagainya. (I Wayan Suardana, 2017: 3) Dalam mewujudkan bagaimana hipokrisi seseorang ke dalam sebuah karya, topeng yang dirasa paling mendekati perihal hipokrisi dalam kehidupan manusia yaitu topeng Cirebon. Hal ini mengacu pada makna dan filosofis topeng Cirebon yang menitikberatkan pada gambarangambaran kehidupan manusia. Alah satu dari sekian banyak Topeng Cirebon pada penggambaran mengenai hpokrisi sendiri akan lebih mengacu pada topeng Cirebon yaitu topeng Panji. Hal ini dikarenkan melihat makna filososis dari topeng Panji yang menggambarkan sebuah kelahiran dari manusia. Topeng panji berwarna putih sebagai simbol dari kehidupan dan budi yang luhur serta penyerahan diri kepada Tuhan. Topeng panji dugunakan sebagai perwujudan seseorang yang bertopeng pada kebaikkan, keluhuran, religiusitas namun tidak pada sifat aslinya.

Melihat hal itu maka topeng Cirebon menjadi sebuah inspirasi dalam mewujudkan bagaimana sifat hipokrit hadir dalam diri manusia dengan menggunakan topeng sebagai penutup muka dan menyembunyikan sifat aslinya. Namun dalam mewujudkannya tidak serta merta mengambil apa yang sudah ada dalam kebentukan topeng Cirebon tapi lebih menghadirkan nuansa topeng dalam kebentukan baru atau lebih menekankan pada sisi subjektif, walaupun tetap dengan tidak meninggalkan makna filosofis dari warna dan mimik ekspresi.

Berkaitan dengan proses perwujudan kali ini, perwujudan hipokrit muncul dalam berbagai ekspresi menurut pengalamanpengalaman hidup yang pernah dilalui, baik dari aspek lingkungan sosial, lingkungan akademik, atau dalam keluarganya. Proses perwujudan dari ide tersebut hadir melalui pengendapan batin serta pembelajaran dari beberapa teori yang bersangkutan dengannya, guna mematangkan sebuah ide 
sebelum melakukan pemindahan ke dalam bentuk-bentuk hingga menyusun sebuah karya. Beberapa unsur-unsur seni rupa menjadi landasan dalam menggambarkan hipokrisi ke dalam sebuah karya visual.

Ada berbagai macam bentuk aliran dan gaya dalam seni lukis seperti realisme, impresionisme, ekspresionisme, naturalisme, dan lain sebagianya, namun dalam merencanakan perwujudan tema hipokrit melalui, gaya abstrak figuratif menjadi acuan utama. Hal ini dikarenakan abstrak sendiri dirasa lebih menitikberatkan pada emosi subjektif dan banyak bermain dengan imanjinasi yang lebih bebas sehingga dirasa mampu memunculkan bentuk-bentuk yang unik dan baru.

Gaya abstrak figuratif akan lebih mempermudah dalam penuangan simbolsimbol yang berkaitan dalam tema Hipokrit ini ke dalam sebuah karya abstrak, sehingga akan mudah diserap serta dihayati, karena pada abstrak figuratif lebih mudah merunut kembali kebentukan asli dari suatu objek. Berbeda dari abstrak murni yang sudah menghilangkan kebentukan asli dari objek tertentu.

Abstrak sendiri dalam kajiannya merupakan seni non figuratif, (Sudarmadji, 2017) namun kata abstrak memiliki konotasi lain yaitu abstrak figuratif. Jika abstrak murni menolak gejala obyektif (panca inderawi) sebagai sumber ide melainkan bertolak pada bentuk atau ujud murni, namun tetap bisa menggetarkan batin seseorang yang menikmati. Maka bisa dipahami bahwa abstrak figuratif seni, abstrak yang masih bisa dirunut bentuk asalnya. (Sudarmadji, 2017) Misalnya deretan rumah-rumah yang tersusun dalam kanvas namun tetap dalam deformasi destruktif sehingga akan tetap terlihat sebagai abstrak.

Dalam perencanaan perwujudan gaya abstrak figuratif ini akan lebih mengedepankan konsep bentuk deformatif. Bentuk deformasi sendiri dalam Kamus Besar Bahasa Indonesia adalah perubahan bentuk atau wujud. (Dendy Sugono,2015: 304) Ada beberapa jenis deformasi antara lain yaitu stilisasi (digayakan/ dihias), distorsi (dilebih-lebihkan), simplifikasi (disederhanakan), dan destruksi (dihancurkan). Karya yang akan dihadirkan akan lebih didominasi dengan pemilihan gaya stilisasi (digayakan/dihias) yang dikombinasikan dengan destruksi (dihancurkan).

Setelah penjabaran mengenai gaya dan aliran, maka dalam perancangan perwujudan, diperlukan pengkomposisian unsur-unsur atau elemen-elemen senirupa, sehingga karya seni yang akan diwujudkan tidak lepas menjauh dari tema yang akan diangkat. Unsur atau elemen seni rupa tersebut diantaranya :

\section{1) Garis}

Secara umum garis adalah suatu goresan atau batas limit dari suatu benda, masa, ruang, warna dan lain-lain. (Fadjar Sidik dan Aming Prayitno) Garis dalam proses penciptaan karya kali ini menjadi unsur penting guna memberikan kesan tegas, kesan lentur, serta sebagai penambah daya artistik dari visual yang akan diangkat ke dalam sebuah karya. Dalam konsep perwujudan ini garis menjadi unsur dekorasi atau unsur pendukung dari suatu objek serta memberi kesan ekspresif pada karya yang dihasilkan dari sapuan kuas ukuran tertentu, sehingga karya yang dihasilkan bisa menimbulkan kesan artistik, gerak, dan arah. Garis juga menjadi batas antara objek satu dan yang lain sehingga objek tidak saling mononjol satu sama lain, tapi garis akan mampu mempertegas antara objek utama dan dan objek pendukung pada lukisan.

\section{2) Warna}

Warna menurut ilmu fisika adalah kesan yang ditimbulkan oleh cahaya pada mata, sedangkan menurut ilmu bahan adalah sebuah pigmen. (Fadjar Sidik dan Aming Prayitno) Warna menjadi menjadi bagian yang erat dengan karya lukis karena warna memberikan nuansa, gerak-irama, memberikan sugesti bentuk-bentuk padat maupun massa. Warna menjadi bagian terpenting dalam lukisan, dari warna bisa 
dilihat nuansa cerah maupun suram suatu lukisan. Dalam perancangan perwujudan ini warna selain memberi nuansa cerah maupun suram juga dilukiskan sebagai penentu suatu objek utama, sehingga bisa dibedakan antara background dan objeknya. Dalam Desain Elementer warna mempunyai banyak pengelompokan dari warna panas, dingin, terang, gelap, cerah, dan suram. Menurut "The Prang System" warna sendiri dikelompokkan menjadi tiga dimensi yaitu:

1. Hue / nama warna : Panas / dinginnya warna

2. Value : Terang / gelapnya warna

3. Intensity : Cerah / suramnya warna. (Fadjar Sidik dan Aming Prayitno)

Dasar pengelompokan warna dalam desain elementer di atas juga terbagi lagi menjadi, pengkomposisian warnawarna komplenter atau pengkomposisian kontras warna sebagai contohnya adalah merah-hijau, ungu-kuning, biru-orange. Penggunaan jenis value atau terang gelapnya warna atas dasar pertimbangan fungsi yang mampu memberikan kontras antara objek dan latar belakang yang lebih tajam, baik terang yang dihadapkan pada gelap maupun sebaliknya. Hal ini diterapkan dalam perancangan penggambaran tentang konsepsi hipokrisi, sehingga secara tersirat mampu menggambarkan keadaan yang kontras antara tindakan dan perkataannya. Selain itu, warna juga berfungsi sebagai pemberi nuansa pada lukisan sehingga mampu memberikan kesan-kesan tertentu pada penikmat hal ini bisa dicapai dengan menggunakan jenis warna intensity yaitu cerah suramnya warna. Perumusan yang diuraikan mengenai tatanan perwarnaan diharapkan dengan warna mampu mewakili setiap sisi konsepsi dari hipokrit.

\section{3) Bidang}

Bidang secara umum adalah permukaan yang rata dan tentu batasnya, dalam artian terlihat jelas batasnya pada sisi-sisinya. (Dendy Sugono,2015: 188) Bidang merupakan tiruan dasar dari setiap bentuk alam nyata ke dalam sebuah bentuk dua dimensional, sedangkan dalam seni rupa bidang merupakan salah satu unsur yang terbentuk dari hubungan beberapa garis. Adapun bidang-bidang yang bersifat tenang, stabil, statis, pada bidang horizontal pada bidang lingkaran memberikan kesan gerak atau lentur dan fleksibel. Bidang juga menjadi ornamen dekoratif yang mengisi setiap bidang kanvas sehingga bisa dicapai keseimbangan komposisi lukisan. Bidang-bidang ini dibuat dengan menorehkan warna pada sketsa awal yaitu pada garis-garis yang saling bertemu membentuk suatu bidang tertentu. Bidang-bidang geometrik (bidang buatan manusia) antara lain meliputi segitiga, lingkaran, persegi, sedangkan bidang alami contohnya bentuk bentuk pada hewan-hewan mikroba amoeba, plakton, atau pada batu karang, langit, laut dan sebagainya. Bentuk alami dalam konteks ini dihasilkan dari leleran cat atau pada efek teknik hisap yang sudah diberi kontur garis pada sisi-sisinya sehingga membentuk bidang tidak beraturan, hal ini dibuat mengingat leleran atau efek dari teknik hisapan pada cat memberikan kesan artistik tersendiri sehingga ada perasaan dalam diri untuk tidak menghapus atau menutup bidang tersebut.

\section{4) Tekstur}

Tekstur adalah nilai raba dari suatu permukaan. Fadjar Sidik dan Aming Prayitno) Ada pula dua jenis tekstur yaitu tekstur semu dan tekstur nyata. Keduanya digunakan sehingga mampu memberikan nilai ilusi optik bagi pengamat sehingga mampu memberi kesan-kesan dalam dan jauh atau fokus dan dekat, serta sebagai penambah daya artistik pada sebuah karya. Tekstur yang menjadi acuan adalah tektur tembok tua berlumut, besi berkarat maupun, tekstur batu-batuan tebing. Selain memberi kesan nilai raba pada suatu permukaan tekstur sendiri meberikan kesan dekoratif yang kuat sehingga mampu menambah daya artistik pada lukisan.

"Di sisi lain tekstur memiliki kualitas plastis karena bisa menimbulkan 
bayang-bayang pada permukaannya, sehingga hal itu menyebabkan karakter yang berbeda-beda. Tekstur juga memiliki nilai ekspresinya sendiri seperti halnya tekstur guratan kayu yang berbeda dengan tekstur karat di besi hal ini mendorong adanya keberagaman nuansa karya antara satu dengan yang lainnya." Fadjar Sidik dan Aming Prayitno)

Atas pertimbangan teknik tersebut maka dalam proses perwujudan hampir semua karya menggunakan tekstur semu. Teknik yang digunakan dalam perancangan perwujudan ini menggunakan kombinasi dua macam teknik yaitu teknik aquarel dan teknik opaque serta beberapa teknik dukungan seperti teknik hisap dan teknik leleran. Teknik aquarel dibuat dengan banyak campuran air sehingga dalam penuangannya teknik ini akan lebih encer dari teknik plakat. Teknik ini banyak digunakan dalam pembuatan latar belakang karena lebih menguntungkan dalam memberikan efek leleran serta efek dari hisapan dengan menggunakan kain dan hasilnya bisa memberikan kesan artistik pada karya. Teknik opaque digunakan dalam tahap pembuatan objek serta detail pada finishing karya karena sifatnya yang menumpuk dan menutup warna sebelumnya.

Dalam proses perwujudanya karya lebih banyak menggunakan media cat akrilik karena sifatnya yang transparan dan aquarel, akan lebih memudahkan dalam pembuatan latar belakang. Selain sifatnya yang transparan cat akrilik juga mempunyai sifat yang cepat mengering. Cat akrilik juga mampu digunakan dalam membuat tekstur, baik itu tekstur nyata maupun semu. Cat minyak bersifat plakat, karena sifatnya yang plakat cat minyak digunakan dalam proses finishing sehingga mampu mencapi detail yang diharapkan.

Setelah menjabarkan mengenai unsur-unsur dalam seni rupa dalam mewujudkan tema hipokrit kedalam sebuah karya maka, pada tahap selanjutnya adalah proses dari perwujudan karya. Mewujudkan sebuah karya seni tidak terlepas dari perlengkapan seperti alat dan bahan yang menunjang agar proses berkarya bisa berjalan dengan maksimal. Bahan-bahan yang mampu menjembatani dalam proses berkarya sebagian besar adalah bahan lukis modern yang bersifat konvesional yaitu seperti:

\section{Kanvas}

Salah satu material pendukung utama dalam melukis adalah kanvas. Kanvas adalah landasan dasar lukisan yang biasanya berasal dari kapas (misalnya cutton duck canvas) (Sucitra, 2015:59), yang ditenun menjadi kain dan pada akhirnya akan direntangkan pada media spanram.

\section{Cat / Warna}

Cat adalah suatu cairan yang dipakai untuk melapisi suatu permukaan suatu benda dengan tujuan memperindah, memperkuat, atau melindungi bahan tersebut. Cat yang digunakan dalam mewujudkan suatu karya seni lukis di sini menggunakan beberapa jenis cat antara lain yaitu:

a. Cat tembok merupakan cat berbasis air yang biasanya digunakan untuk melapisi tembok rumah, gedung dan lain sebagainya.

b. Cat akrilik

Cat akrilik merupakan cat berbasis air sebagai pengencer cat juga merupakan cat modern yang diformulasikan dari sintesis polimer umumnya disebut sebagai akrilik polimer emulsi.

\section{Air}

Digunakan untuk mengencerkan cat serta mencuci kuas.

$4 . \quad$ Kuas

Salah satu bahan utama untuk menerapkan cat di atas permukaan media adalah kuas. (Sucitra, 2015: 88) Kuas yang digunakan yaitu kuas yang biasa dipakai pada media cat minyak yang berbentuk pipih, persagi, runcing dan bulat bermerk V-tec. Berbagai jenis ukuran digunakan mulai dari $00-12$, ini dimaksudkan 
agar pada saat melukis tidak mengalami kesulitan dalam mengecat bidang besar maupun kecil.

5.

Palet cat

Palet cat merupakan tempat mencampur cat yang akan diterapkan pada kanvas selama proses melukis.

6. Pisau palet

Pisau palet merupakan semacam pisau dipakai untuk mencampur cat minyak atau akrilik dalam proses melukis.

7. Kain lap

Kain lap digunakan untuk membersihkan kuas setelah dicuci dan sebagai alat bantu dalam penerapan teknik hisap.

Seni lukis memiliki sejarah perkembangan yang panjang demikian juga tujuan dalam setiap era. Selain memiliki banyak aliran, seni lukis juga memiliki banyak teknik dalam penuangannya. Setiap seniman memiliki teknik yang berbeda-beda untuk menghasilkan sebuah karya. Beberapa macam teknik yang akan digunakan dalam proses mewujudkan gagasan kedalam sebuah karya yaitu:

\section{Teknik Transparan}

Teknik transparan merupakan teknik melukis dengan menggunakan sapuan warna tipis dan banyak air, sehingga lukisan yang dihasilkan bernuansa transparan.

2. Teknik leleran

Teknik leleran adalah sebuah pengembangan dari teknik basah, teknik ini memanfaatkan leleran cat yang encer dan banyak air.

\section{Teknik hisap}

Teknik hisap merupakan teknik yang dikerjakan dengan cara menghisap cat di atas kanvas dengan bantuan kain lap, sehingga cat yang terangkat atau terhisap akan meninggalkan bekas lipatan pada kain. Teknik ini menggunakan kain yang yang mudah menyerap air seperti kaos t-shirt atau kain pel, handuk, spon, dan lain sebagainya.

4. Teknik kering

Teknik kering yaitu teknik yang dibuat dengan tidak mencampurkan air sebagai pengencer namun cat digunakan langsung dari tube cat pada saat cat dalam keadaan kental atau padat, sehingga bisa memberikan efek plakat atau menutup permukaan kanvas dari warna sebelumnya. Teknik kering digunakan sebagai tahapan akhir dari melukis yaitu saat finishing atau saat membutuhkan detail yang kuat pada suatu objek tertentu.

Menurut Graham Wallas ada beberapa tahapan yang dilakukan dalam proses kreatif yaitu: persiapan, inkubasi atau pengendapan, iluminasi, verifikasi/ pengujian yaitu tahap di mana ide atau kreasi diuji terhadap realitas dalam bentuk wujud karya. Dalam tahap ini adalah tahap di mana ide mulai dituangkan ke dalam karya atau tahap penciptaan hingga pada deskripsi karya. Tahapan-tahapan tersebut adalah sebagai berikut:

1. Tahap persiapan dalam persiapan untuk melukis tahap pertama yang dilakukan terlebih dahulu adalah dengan tahap pembuatan kanvas terlebih dahulu dengan cara memplamir atau mencat permukaan kain kanvas mentah yang telah dibentangkan. Dalam tahap ini termasuk juga dalam persiapan alat dan bahan yang digunakan untuk melukis seperti yang sudah dijabarkan pada penjabaran sebelumnya.

2. Tahap inkubasi adalah tahap di mana seakan-akan melepaskan diri untuk sementara dari masalah atau ide dari gagasan yang ada dan mengendapkannya dalam benak. Tahap ini dilakukan dengan cara melakukan perenungan serta penghayatan gagasan yang sesuai untuk divisualisasikan.

3. Tahap iluminasi atau tahap inspirasi

Tahap di mana timbulnya inspirasi atau gangguan baru dalam penuangan gagasan ke dalam sebuah wujud karya.

4. Tahap penciptaan karya 
Tahapan ini termasuk dalam persiapan perwujudan suatu gagasan ke dalam karya seni dalam hal ini adalah seni lukis. Kesiapan alat serta bahan sangat diperlukan pada tahap ini. Mempersiapkan material seperti cat, kuas, air, ember, kanvas, dan sebaginya.

Proses perwujudan ide ke dalam sebuah bentuk karya merupakan bagian yang penting dalam pendokumentasian sebuah karya seni karena memuat tahap-tahap dari awal pembuatan karya hingga akhir. Tahap awal adalah pematangan ide gagasan yang timbul sehingga melahirkan sebuah konsep perwujudan sebuah karya hingga pada proses pengerjaan karya.

Dalam penciptaan karya Tugas Akhir ini dibuat 20 karya, dan terdapat berbagai macam teknik dan proses pengerjaan yang mendukung dalam proses berkarya, sehingga bisa menghasilkan karya yang beragam serta tidak monoton. Namun bagian yang terpenting dari itu semua adalah hasil akhir karya seni yang berupa lukisan ini mampu memberi makna yang positif bagi diri pribadi maupun bagi orang sekitar.

\section{PEMBAHASAN KARYA}

Karya seni tercipta darilatar belakang suatu permasalahan, gejala sosial, dan lain sebagainya. Dari permasalahan yang ada, seorang perupa mengolahnya menjadi suatu karya yang kreatif dengan berbagai macam bentuk dan gaya. Kekreativitasan perupa dapat dilihat dari visual karya yang diwujudkan dan sesuatu hal yang melatarbelakangi terciptanya suatu karya sehingga karya bisa ditampilkan dalam berbagai rupa dan gaya.

Dalam pembahasan karya dijelaskan mengenai makna dari simbol-simbol yang digunakan, latar belakang terciptanya karya serta unsur atau elemen-elemen seni rupa yang digunakan dalam perwujudan karya lukis. Adanya pendeskripsian karya akan mempermudah apresiator seni dan masyarakat umum menghayati dan memahami karya seni, sehingga diharapkan pendeskripsian karya akan mengurangi terjadinya kesalahpahaman dalam mengartikan atau memahami karya seni. Semoga karya-karya yang diciptakan dengan tema besar "HIPOKRIT SEBAGAI IDE PENCIPTAAN KARYA LUKIS" dapat memberikan manfaat bagi diri pribadi maupun publik masyarakat.

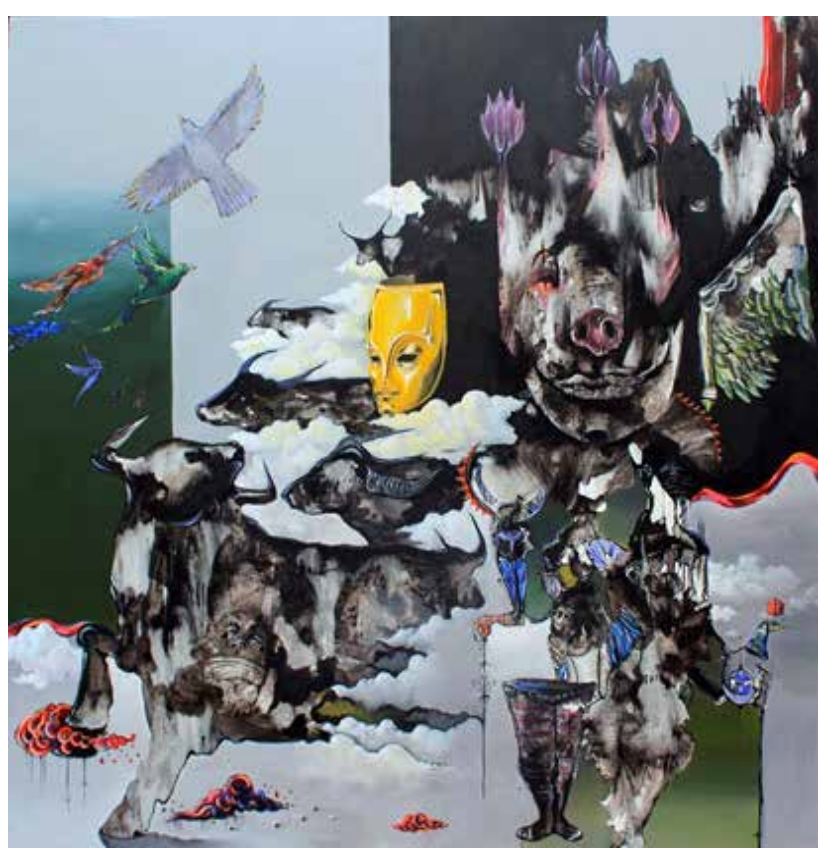

Gambar 1. Judul: "Manusia dan Kerbau" Media: akrilik di atas kanvas Ukuran: $130 \times 130 \mathrm{~cm}$, 2017 (Dokumentasi: Goon Hadi)

Karya ini terinspirasi dari pengalaman pribadi saat di mana kesadaran tentang hipokrisi belum sepenuhnya disadari, sehingga dengan mudah mengumbar berbagai nasehat atau merasa lebih memiliki standar moral yang lebih baik ketimbang yang lain.

Pada karya ini konsepsi tentang hipokrisi dihadirkan lewat sesosok figur abstraksi manusia yang bertopeng juga menghadirkan figur kerbau dan burung dalam lukisan, kerbau sebagai simbol kedudukan, kekayaan serta kepercayaan, sedangkan burung sebagai simbol dari spiritual, kasih, kesetiaan dan keadilan.

Karya ini dilukiskan dengan warna yang cenderung gelap seperti hitam, abu-abu dan hijau, sehingga memunculkan kesan dalam dan magis serta warna kuning keemas-emasan pada topengnya yang 
menandakan sesosok figur yang selalu bertopeng pada kemakmuran, bersahaja, baik dan memberikan berkat pada orang lain. Makna dari karya ini adalah seseorang yang bertopeng pada kasih, kepercayaan, religiusitas namun semuanya itu dilakukan hanya untuk mengejar kepentingan pribadi seperti kedudukan, kekayaan, jabatan, pujian dan lain sebagainya.

\section{Judul: "Adu Domba"}

Media: akrilik di atas kanvas

Ukuran: 150 x 100 cm, 2017

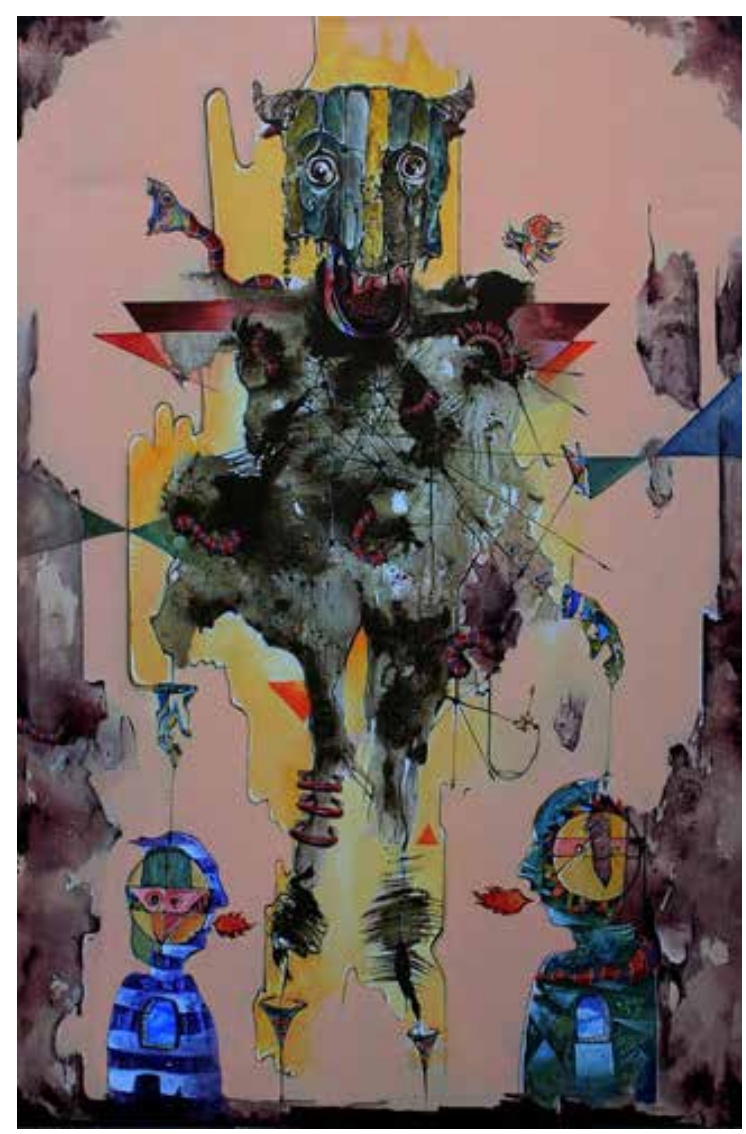

Gambar 2. Judul: "Adu Domba" edia: akrilik di atas kanvas Ukuran: $150 \times 100 \mathrm{~cm}, 2017$ (Dokumentasi:Goon Hadi)

Karya ini masih terinspirasi dari karya sebelumnya. Menghadirkan konsepsi tentang hipokrit dengan sesosok figur abstraksi manusia dengan topeng berwarna hijau sebagai simbol kebijaksanaan serta keadilan dan pewarnaan yang cenderung terang, hangat, dan manis sebagai simbol dari konsepsi hipokrisi yang cenderung manis diluar namun buruk dalam jiwanya.
Pada bagian bawah juga terdapat dua figur manusia dengan api di depan mulutnya sebagai tanda seseorang yang marah atau saling bertikai. Simbol-simbol yang terkait selain topeng adalah ular yang melilit dan burung. Selain memiliki makna filosofi yang positif yaitu sebagai penawar racun, ular juga kerap menjadi simbol dari kelicikan, dan hipokrisi sendiri salah satu indikasi yang mudah dibaca adalah sebagai seseorang yang licik seseorang yang pandai berkata-kata demi kepentingan pribadinya saja. Burung memiliki simbol spiritual, kasih, dan kesetiaan.

Dua sifat yang kontras dalam satu pribadi.Padakaryaberjudul "AduDomba" ini memiliki makna bagaimana hipokrisi yang ada pada diri ataupun seseorang mampu memecah belah sekelompok kaum tertentu dengan kepandainya menyembunyikan keburukan sifat aslinya, sehingga dari hal tersebut justru mengakibatkan pertikaian antar satu orang dengan orang yang lain, kelompok, atau kaum tertentu.

\section{Judul: "Potret Hipokrisi"}

Media: akrilik di atas kanvas

Ukuran: 60 x $80 \mathrm{~cm}, 2017$

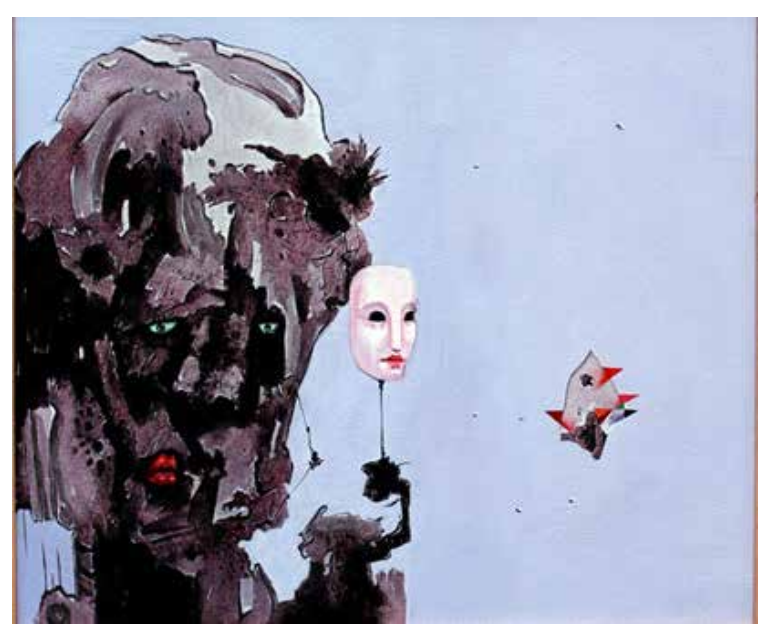

Gambar 3. Judul: "Potret Hipokrisi" Media: akrilik di atas kanvas Ukuran: 60 x 80 cm, 2017 (Dokumentasi: Goon Hadi) 
Melalui karya ini hipokrisi ditampilkan figur orang bertopeng berwarna putih. Topeng pada lukisan ini masih mengacu referensi topeng Cirebon yaitu topeng panji dengan karakter dan ciri berwarna putih dan minim oranmen serta memiliki garis kerut wajah yang halus sebagai simbol dari kebudiluhuran, dekat dengan Illahi dan sebagai seseorang yang suci. Pada objek figur digambarkan dengan tekstur yang memiliki kesan rapuh, kotor, dan busuk.

Kedua hal tersebut mencoba mengungkapkan bagaimana hipokrisi yang bertopeng pada kebaikan, budi luhur, dan religius namun pada sifat aslinya tidaklah demikian. Pada latar belakang lukisan menampilkan warna ungu muda dan polos hal ini dimaksudkan agar karya yang ditampilkan mampu memberikan fokus yang jelas pada objek figur seorang hipokrit. Ornamen abastraksi pada bagian kanan karya sebagai penyeimbang komposisi dan pengisi ruang.

\section{E. KESIMPULAN}

Tema dalam Tugas Akhir ini berjudul "HIPOKRIT SEBAGAI IDE PENCIPTAAN KARYA LUKIS", berangkat dari pengalaman pribadi serta berdasar pada pengamatan dari peristiwa maupun perilaku sosial sehari-hari dalam beragama dan bermasyarakat. Hal tersebut dirasa cukup memberi pengaruh dan berdampak pada diri untuk kehidupan selanjutnya. Pembelajaran dalam hal ini adalah mengenai bersikap dan menyikapi diri pribadi terhadap lingkungan sekitar. Bagaimana bersosial dengan masyarakat sekitar, sehingga bisa menimbulkan dampak yang positif terhadap lingkungan sekitar.

Hipokrisi dilakukan hanya untuk mengejar keuntungan diri semata, jabatan, kekuasaan, pujian, dan religius padahal perilakunya berbanding terbalik. Oleh karena itu, tema hipokrit sebagai ide penciptaan karya lukis Tugas Akhir dalam konteks ini, dikerucutkan kepada perihal hipokrisi yang berdampak negatif, menghancurkan buruk pada lingkungan sekitar.

Pendalaman materi mengenai hipokrisi diri akan terus berlanjut guna membangun pribadi yang lebih baik terhadap keluarga, masyarakat, maupun negara. Dalam pembelajaran kedepannya, diharapkan akan lebih matang dan mendetail dalam mengonsepsikan perihal hipokrisi serta memiliki pemahaman yang lebih mengenai hipokrisi.

Dengan demikian maka kritik, saran serta masukan-masukan sangatlah membantu, guna pembenahan diri menjadi pribadi yang lebih baik dan dalam kehidupan proses berkesenian yang lebih mapan dan matang.

\section{KEPUSTAKAAN \\ Buku}

Jung, C. G. 1966. Two Essays on

Analytical Psychology; Collected Work Vol 7. New York: Princeton University Press.

N. Drijarkara S.J., 1978. Filsafat

Manusia Yogyakarta: Yayasan Kanisius.

Marianto, M. Dwi Marianto. 2011. Menempa Quanta Mengurai Seni. Yogyakarta: Badan Penerbit ISI Yogyakarta.

Moliono, Anton M. (ed.). 1989. Kamus

Besar Bahasa Indonesia, edisi ke 1, Jakarta: PT Gramedia Pustaka Utama.

Sidik, Fadjar \& Aming Prayitno. Nirmana. Yogyakarta: STSRI-ASRI

Sucitra, I Gede Arya. 2013. Pengetahuan Bahan Lukisan. Yogyakarta: Badan Penerbit ISI Yogyakarta.

Sugono, Dendy. 2015. Kamus Besar Bahasa Indonesia. edisi ke-4. Jakarta: PT Gramedia Pustaka Utama.

Sumardjo Jakob. Filsafat Seni. 2000. Bandung: Penerbit ITB.

Supangkat, Jim \& Goenawan Muhammad (ed). 1976. Seni Lukis Indonesia Baru; Sebuah Pengantar. Jakarta: Dewan Kesenian Jakarta.

Wibisono, I. Wibowo. 1977. Sebuah Bunga Rampai Dari Sudut-Sudut Filsafat; Seri Driyakarya 4. Yogyakarta: Yayasan Kanisius. 
Sudarmadji. 2002. Seni Rupa Dalam Abad XX Di Dunia Barat Dan Indonesia dalam sepintas. Seni: Jurnal Seni Rupa DKJ_002

Yangni, Stanislaus. 2012. Estetika Seni Rupa. Yogyakarta: Erupsi Akademia.

Makalah

Rosidi, Dedeng, Karakteristik Manusia Munafiq. 2007. Makalah S-3 Program Studi Pendidikan Islam Program Pasca Sarjana S-3 Universitas Islam Negri Sunan Gunung Djati, Bandung.
Website

Grey, Elmer L. Hypocrite, http://www. stjhonluteran-elyria.org

Fr. Lanfaranco M. Fedrigotti S.D.B, The Multi-Layered Meaning of "Hypocrisy" in the Gospels, Http:// archive.hsscol.org.

Sany, Yudhanty Parama, "Tari Topeng dan Pertunjukannya dalam Upacara Adat Mapag Sri”, Http//:www.digilib.ui.ac. id

Suardana, I Wayan. "Struktur Topeng Bali Klasik", Http//:www.budaya-indo. com 